特集 : シミュレーションによる固液・電極界面の解析

\title{
3. 水/Pt電極界面における電気化学反応シミュレーション
}

\section{森川 良忠}

\section{1. はじめに}

量子力学, 電磁気学, 統計力学, といった物理学の基 本法則のみに基づく物質の電子状態計算手法である第一 原理シミュレーションは近年大きく発展し, 基礎物質科 学の分野における様々な現象の解明に大きな役割を果た してきた。ささに，現象の理解に基づいて物質の性質を 予測し, 新しい有用な物質を設計するための強力なツー ルとして役立てる試みがなされ，コンピューテーショナ ル・マテリアル・デザイン $(\mathrm{CMD})$ と呼ばれる新しい研究 分野として, 基礎物質科学のみならず，産業やエネル ギー，環境分野等，幅広い分野に応用されようとしてい $3^{1,2}$. 固体表面上の分子の吸着や反応過程については第 一原理シミュレーションの主要な題材として多くの研究 に取り上げられてきた。現在では第一原理シミュレー ションは, 良く規定された表面を用いた実験結果と非常 に良く一致し，実験結果を解釈するために極めて重要な 役割を果たしている。一方, 固液界面の構造や電気化学 反応過程については, 固体表面の構造に加え, 溶媒の効 果, さらには電極電位の効果を取り入れる必要があり, 電気化学分野への第一原理シミュレーションの応用は遅 れていた。しかしながら, 最近, 電気化学反応過程への 第一原理シミュレーション手法が急速に進歩してきてお り，電極界面での反応の素過程について明らかにし，そ れらの電極電位依存性や電極金属依存性についても調べ る事が可能になってきている. 従来の実験的な電気化学 反応の研究では反応素過程を直接見る事はできず, 反応 物と生成物について反応速度論的な考察を行うことに よって反応機構が推測されてきた. 第一原理シミュレー ションによって反応の素過程が原子レベルで初めて直接 調べる事が可能になり, 電気化学の分野において歴史的 な転換期であると言える。本稿ではこれら，第一原理シ ミュレーション手法による固液・電極界面研究の最近の 発展を紹介する.

\section{2. 水/ $\mathrm{Pt}$ 電極界面での第一原理分子動力学シミュ レーション}

電極表面の構造に加えて, 溶媒の構造, および, 電極 電位の効果を取り入れて, 電極界面の反応を出来る限り 精度よく取り扱うシミュレーションを我々のグループで 行ってきた ${ }^{3-6}$. 水素発生反応の第一段階であるボルマー 過程の反応のダイナミクスを調べることに成功した。こ のシミュレーションでは Fig. 1 に示す様にPt基板を 3 層の スラブでモデル化し, 溶媒である水も露に計算モデルに

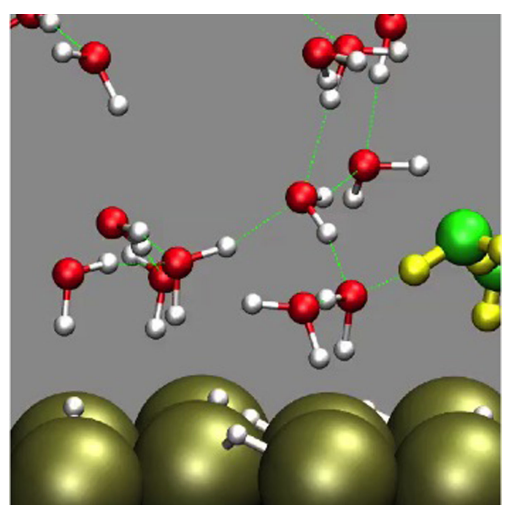

Figure 1. (Color online) 水 $/ \operatorname{Pt}(111)$ 電極界面モデル. $\operatorname{Pt}(111)$ 表面 $3 \times 2 \sqrt{3}$ ユニット・セルを用い, 水は 32 分子含んでい る.プロトンが一つ水和している。

取り入れ，準安定な構造をサンプリングするために第一 原理分子動力学シミュレーションを数万から十万ステッ プ程度行っている. 電極界面での電場の効果を取り入れ るために, Ptスラブに余剰電荷を与え, 真空側には有効 遮蔽媒質 (Effective Screening Medium, ESM) と呼ばれる補 償電荷を真空側に置くことによって, Pt 電極と水の層の 間に電場を生じさせる.Ptに与える余剩電荷を調節する ことによって界面電気二重層, すなわち真空準位から 測った電極電位を制御することが可能である。このシ ミュレーションについては以前に本誌でも紹介したので, 詳細はそちらにゆずる7,8. この方法では電極界面の構造 と反応過程を最も正確にモデル化していると言える。し かしながら,このシミュレーションに必要な計算機資源 は莫大で, 大規模なスーパー・コンピューターが潤沢に 使用できる環境が必要である。

3. バイレイヤー・モデルによる水/Pt 電極界面での 水素発生反応シミュレーション

前節で述べた第一原理分子動力学法による電極界面の シミュレーションでは, 無数に存在する準安定な水の構 造を統計力学的にサンプルし, さらに反応過程の動的な 側面も詳細に調べる事ができるので, 固液界面での化学 反応過程を研究する上では理想的な手法である。しかし ながら, 分子動力学法によって多数の配置を十分サンプ リングするには, 一つの反応の素過程について数万から 十万ステップの分子動力学ステップを計算する必要があ る. 多数の反応経路について電極電位や電極金属依存性 を調べるためには膨大な計算が必要になってくる. 


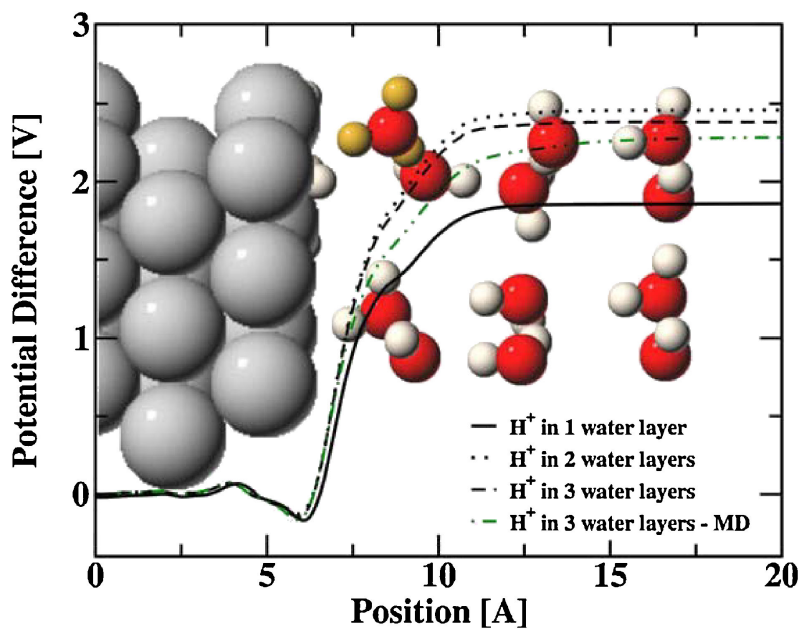

Figure 2. (Color online) 水/ $\mathrm{Pt}(111)$ のバイレイヤー・モデル バイレイヤーを 1 層, 2 層, 3 層用いた場合の静電ポテン シャルのプロファイルを実線, 点線, および, 破線でそれぞ れ示してある. Reference 9 から転載.

Nørskov らはPt表面上に氷の結晶を構成する水分子のバイ レイヤーを載せることによって電極界面を上手くモデル 化することに成功した ${ }^{9,10}$. 本節と次節ではこの静的なバ イレイヤー・モデルを用いた研究について紹介する.

バイレイヤー・モデルとは Fig. 2 に示すように, 基板 の $\operatorname{Pt}(111) \sqrt{3} \times \sqrt{3}$ ユニット・セル内に二種類の異なった 配位を持つ水分子で構成されている。一つの水分子は分 子面を表面平行方向にしたものであり，もう一つの水分 子は表面に垂直方向に $\mathrm{OH}$ 結合を持つ。バイレイヤー 一層が $\mathrm{Pt}(111)$ 表面を覆った表面の水の被覆率は $2 / 3 \mathrm{ML}$ に なる. 六方晶水の格子定数と Ptの格子定数は $7 \%$ 近くミ スマッチしているので, 理想的な界面ではないが，近似 的に水と $\mathrm{Pt}(111)$ 表面の界面構造をモデル化していると考 えられる。

このバイレイヤー・モデルを用いて水素酸化反応，お よび，その逆反応である水素発生反応について詳細な研 究が行わ机た。水素極においては，電極が負に帯電する と，その電荷を打ち消すだけのプロトンが界面第一層の バイレイヤーに拡散してきて (Fig. 2)，へルムホルッ層を 形成する。この電極界面とプロトンが水和したバイレイ ヤーとの間で電気二重層が生じる。電極電位は, この界 面第一層にたまるプロトンの被覆率（表面 Pt 原子あたり の界面バイレイヤー中にある水和プロトンの数）に依存 して決まる. 第一原理シミュレーションでは, 大きなュ ニット・セルを用いて, 界面第一層に存在するプロトン の数を調節する事により，様々な電極電位の計算を行う ことが可能になる。プロトンの被覆率を変化させた際の 電極電位は, 水のバイレイヤーの外側の真空準位を基準 にした電極の仕事関数の変化から計算する事ができる. 現実の電極界面では水の層は非常に愿いが，バイレイ ヤー・モデルにおいては 1 層から 3 層程度のバイレイ ヤーを用いるだけで電極電位は十分再現できることが確 かめられている. Figure 3 はさまざまな電極電位での界面 に蓄積された自由エネルギーを示す。この計算では $1 \sim 3$ 層の水のバイレイヤーを $\mathrm{Pt}(111)$ 表面と接触させたモデル を用いている。この曲線の極率から界面電気二重層の電
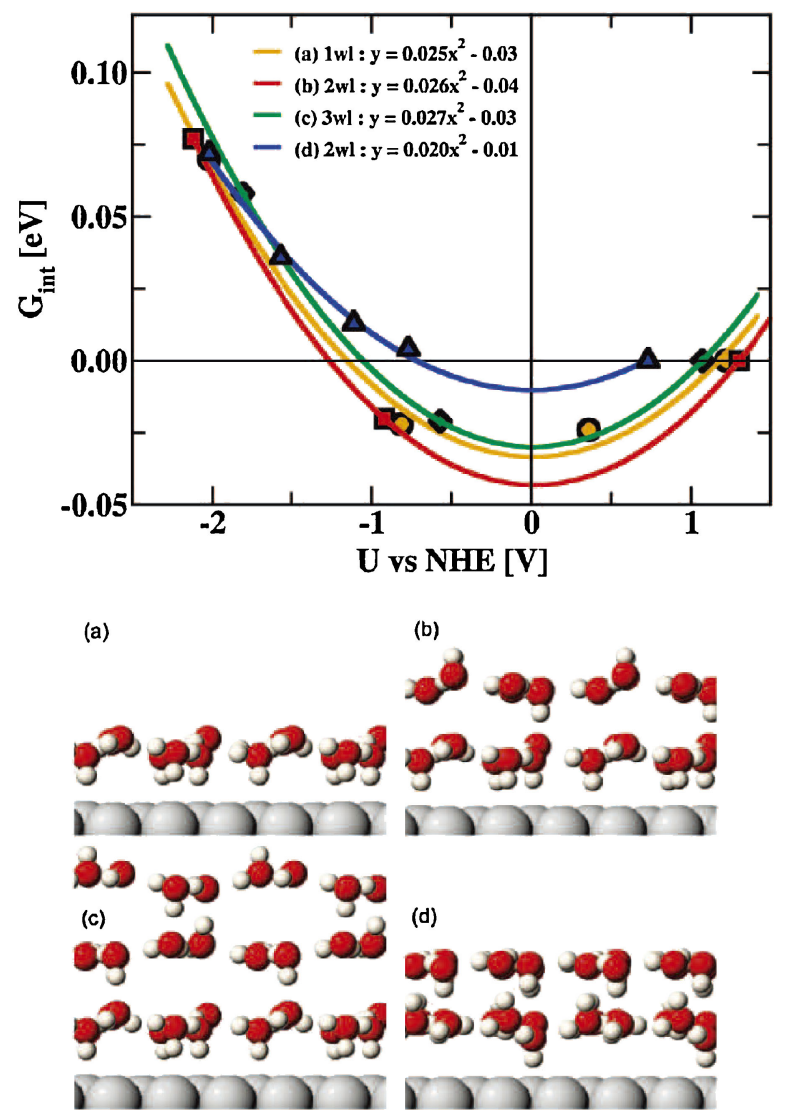

Figure 3. (Color online) 水/ $\operatorname{Pt}(111)$ 電極界面の積分自由エネ ルギーをNHEに対する電極電位 $U$ の関数としてプロットし た図。 バイレイヤーを 1 層, 2 層, 3 層用いた結果と, 界面第 一層のバイレイヤーの構造を水素が上向きの構造に替えた場 合についてそれぞれ示してある. Reference 10 から転載.

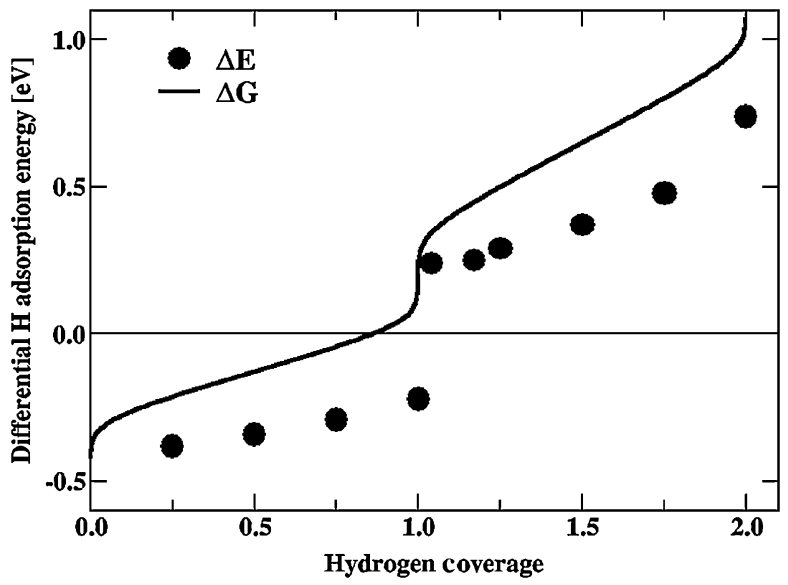

Figure 4. 水素の吸着エネルギーと吸着自由エネルギーの被 覆率依存性. Reference 10 から転載.

気容量が計算でき, バイレイヤー 1 層のモデルでは $\mathrm{C}=22.7 \mu \mathrm{F} / \mathrm{cm}^{2}, \quad 2$ 層のモデルで $\mathrm{C}=23.6 \mu \mathrm{F} / \mathrm{cm}^{2}, \quad 3$ 層 のモデルで $\mathrm{C}=24.5 \mu \mathrm{F} / \mathrm{cm}^{2}$, となり, いずれも実験值の $20 \mu \mathrm{F} / \mathrm{cm}^{2}$ と比較的良く一致しており, バイレイヤー・モ デルが界面での電気二重層の性質を良く再現しているこ とがわかる. 水素発生反応がおこる電極電位では, Pt 表 面に水素原子が吸着しているが, 吸着水素の被覆率も計 算から求められる. Figure 4 に水素の $\operatorname{Pt}(111)$ 表面上への 


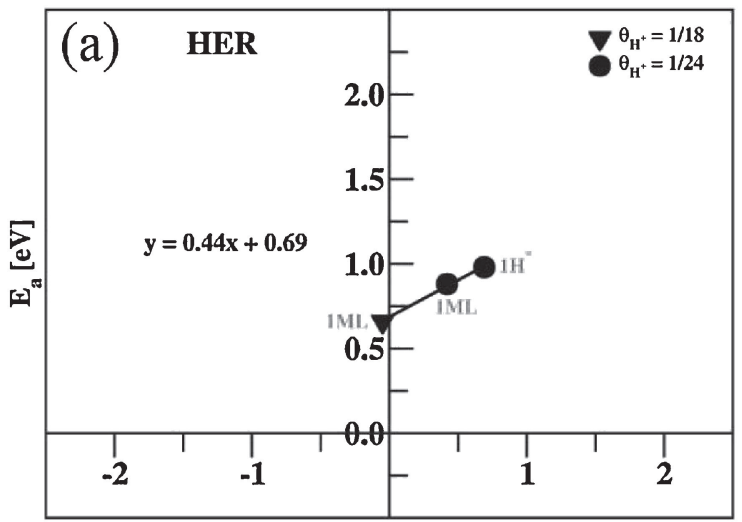

U vs. NHE [V]

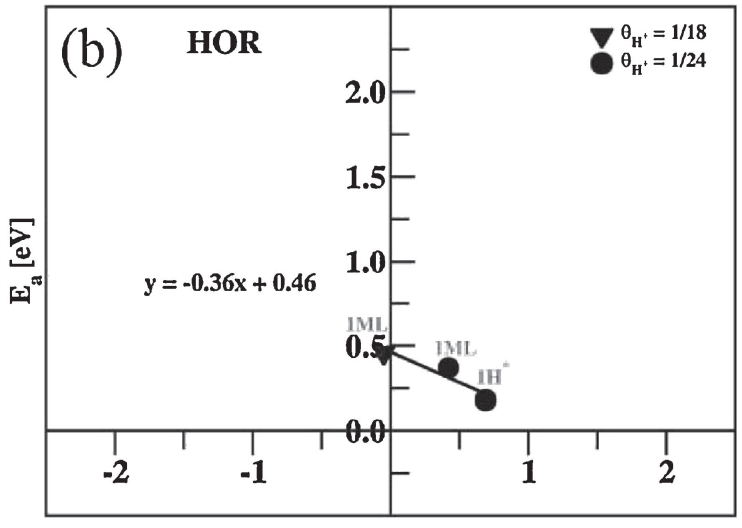

U vs. NHE [V]

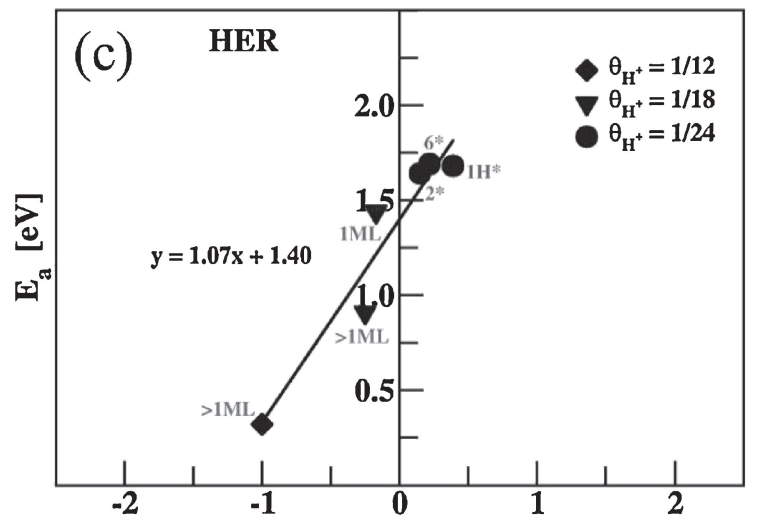

U vs. NHE [V]

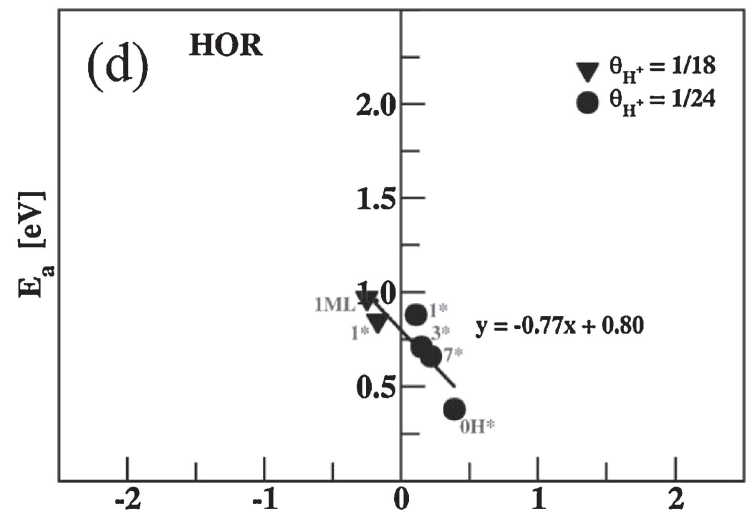

U vs. NHE [V]

Figure 5. (a), (b) ボルマー過程の水素発生反応，および，水素酸化反応の活性化エネルギーの電極電位依存性。(c)，(d)へイロ フスキー過程の活性化エネルギーの電極電位依存性. Reference 10 から転載.

微分吸着エネルギーの被覆率 $\left(\theta_{\mathrm{H}}\right)$ 依存性が示してある。 水素原子の吸着エネルギーに加えて，吸着水素の振動状 態と配置のエントロピーの寄与を加えて吸着の際の自由 エネルギー変化を計算している． $\theta_{\mathrm{H}} \leq 0.86 \mathrm{ML}$ では $\Delta G_{\mathrm{H}^{*}}$ は負になり，標準状態の水素と平衡にある場合は Pt(111) 表面は $0.86 \mathrm{ML}$ の水素で覆われていることがわかる．水素 の被覆率は電極電位に依存して変化する。それは溶液中 のプロトンと吸着水素との化学平衡を考える事により求 める.

$$
\mathrm{H}^{+}+\mathrm{e}^{-}+* \rightarrow \mathrm{H}^{*}
$$

ここで「*」は表面の空いている吸着サイトを示し，「H*」 は吸着水素原子を示す。電極電位 $U=0 \mathrm{~V}$ (vs. NHE) の時, 左辺の $\mathrm{pH}=0$ の水溶液中のプロトンは標準状態の気体の 水素と平衡にある．電極電位がゼロではないとき，左辺 の電子は電極のフェルミレベルに入るので, 左辺の自由 エネルギーは $-e U$ に依存して変化する。よって, 電位が $U$ の電極が $\mathrm{pH}=0$ の水溶液と接しているとき，水素の被 覆率は $\Delta G_{\mathrm{H}^{*}}=-e U$ として求める事ができる。たとえば, $U=0 \mathrm{~V}$ の時は水素の被覆率は $0.86 \mathrm{ML}$ になる。

つぎに，界面での水素発生反応について考える．水素 発生反応では水和したプロトンが電極で電子を受け取っ て吸着水素になるボルマー過程,

$$
\mathrm{H}^{+}+\mathrm{e}^{-} \rightarrow \mathrm{H}^{*}
$$

水和したプロトンが電極表面の吸着水素と直接反応して
水素分子が発生するへイロフスキー過程,

$$
\mathrm{H}^{*}+\mathrm{H}^{+}+\mathrm{e}^{-} \rightarrow \mathrm{H}_{2}
$$

および，吸着水素どうしが会合して水素分子となる夕ー フエル過程,

$$
\mathrm{H}^{*}+\mathrm{H}^{*} \rightarrow \mathrm{H}_{2}
$$

の三つの素過程が関与していると考えられている。それ ぞれの過程の活性化障壁が，このバイレイヤー・モデル を用いて求められた。ただし, ボルマー過程やへイロフ スキー過程では界面第一層のバイレイヤー中のプロトン が電極から電子を受け取って吸着水素や水素分子に変化 するのであるから，計算モデル中のバイレイヤーに含ま れるプロトンの数が変化し, よって電極電位も変化して しまう。特に小さい界面ユニット・セルのモデルを用い ると反応の前後での電極電位の変化が大きく，反応の活 性化障壁が正しく求める事ができなくなる。そこで，複 数のサイズのユニット・セルを用いて反応シミュレー ションを行い, ポテンシャルの変化がゼロになる極限に 外挿する方法が考案された. Figure 5 にこの方法によるボ ルマー過程, および, ヘイロフスキー過程の活性化障壁 の電極電位依存性が電位依存性を示す。水素発生反応の ボルマー過程の活性化障壁が, 電極電位 $U=0 \mathrm{~V}$ のき $0.69 \mathrm{eV}$, 逆反応である水素酸化反応のボルマー過程の活 性化障壁は $0.46 \mathrm{eV}$ である。両者の違いは両反応の反応工 ネルギーの違いを反映している。同様に，へイロフス 


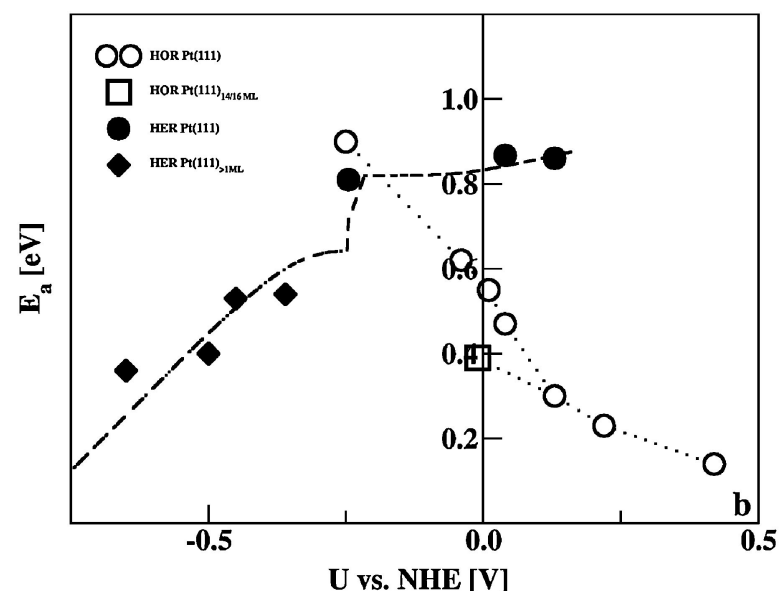

Figure 6. ターフェル過程の活性化エネルギーの電極電位依 存性. Reference 10 から転載.

キー過程についても, 水素発生反応では $1.40 \mathrm{eV}$, 水素酸 化反応で $0.80 \mathrm{eV}$ となり, 両反応ともボルマー過程の方が かなり低い活性化障壁を持つことがわかる。

ターフェル過程については, 電子移動を伴わないので, 電極電位には依存しないと考えられるが，上で述べたよ うに電極電位に依存して水素の被覆率が変わり, それに 応じて水素の吸着自由エネルギーが変化するために，水 素の会合脱離（水素酸化反応の場合は解離吸着）過程で あるターフェル過程の活性化障壁も電極電位に依存して 変化する.その計算結果を示したのがFig. 6である. 同じ 被覆率でも吸着水素の配置によって活性化障壁が依存す るが， $U=0 \mathrm{~V}$ での水素発生反応の夕ーフェル過程の活性 化障壁は約 $0.8 \mathrm{eV}$, 水素酸化反応の場合は約 $0.4 \mathrm{eV}$ 程度で あり, へイロフスキー過程よりもかなり活性化障壁が低 く, ターフェル過程が優勢である事がわかる.

4. バイレイヤー・モデルによる水/Pt 電極界面での 酸素還元反応シミュレーション

酸素還元反応に関しても，バイレイヤー・モデルを用 いて詳しい研究が行われた ${ }^{11}$. Pt 電極電位が高くなってい くと, 電極表面は $\mathrm{OH}$ で覆われる. Figure 7 の下のパネル に示す様に, 吸着 $\mathrm{OH}$ は界面の水と水素結合し, バイレ イヤー構造を形成する。電極電位が高くなってくると

$$
\mathrm{H}_{2} \mathrm{O}^{*} \rightarrow \mathrm{H}^{+}+\mathrm{e}^{-}+\mathrm{OH}^{*}
$$

の反応によって界面第一層バイレイヤー中の水がプロト ンを放出して吸着 $\mathrm{OH}$ に変化する。吸着 $\mathrm{OH}$ の自由エネル ギーの被覆率依存性を Fig. 7 の上のパネルに示す。図の破 線はある被覆率における平均の吸着自由エネルギーであ り，実線は微分吸着自由エネルギーである。この計算で は放出した水素の化学ポテンシャルは標準状態の水素ガ スに等しいとして計算している。 $\theta_{\mathrm{OH}}=1 / 3 \mathrm{ML}$ で微分自 由エネルギーにとびがあり， $1 / 3 \mathrm{ML}$ 未満では吸着微分自 由エネルギーは $0.79 \mathrm{eV}$ に対して $1 / 3 \mathrm{ML}$ を超えると $1.16 \mathrm{eV}$ にど゙. $1 / 3 \mathrm{ML}$ の $\mathrm{OH}$ が吸着した構造は, ちょう ど界面のバイレイヤー中の水のうち, 半分が解離して $\mathrm{OH}$ になった状態に対応する。電極電位依存性については, 水素極と同様に標準状態の水素ガスと $\mathrm{pH}=0$ の水溶液中
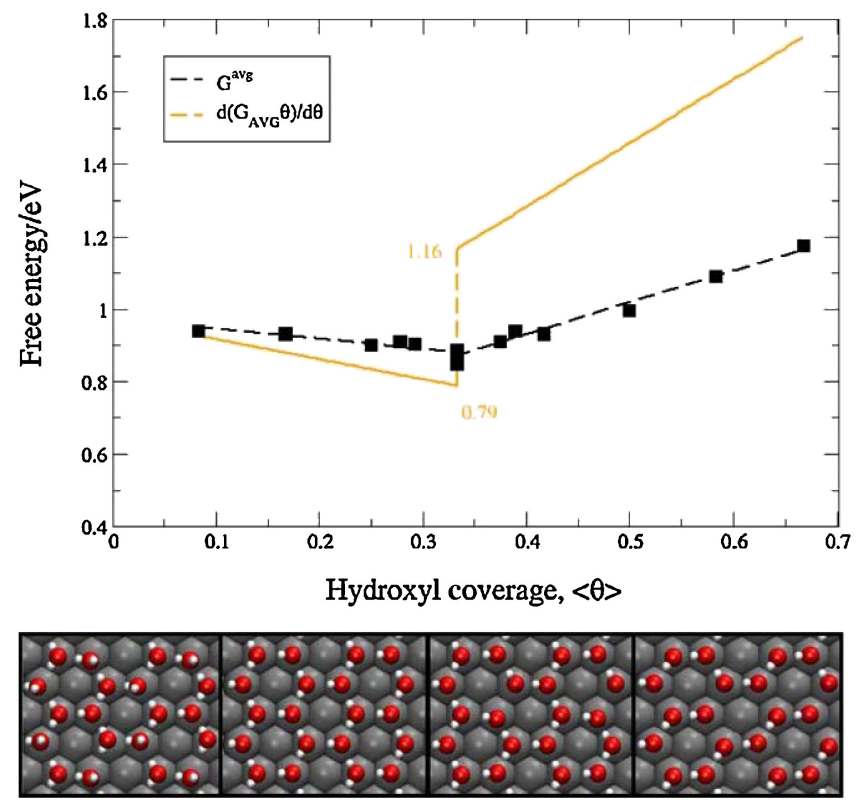

Figure 7. (Color online) 吸着 $\mathrm{OH}$ の生成自由エネルギー. 破 線は平均自由エネルギー, 実線は微分自由エネルギーを示す. 異なる $\mathrm{OH}$ 吸着被覆率での構造については下のパネルに示さ れる. Reference 11 から転載.

のプロトンとの化学平衡を考えることにより取り入れる ことが出来る.すなわち, $U=0.79 \mathrm{~V}$ 以下の電位では $\mathrm{OH}$ は吸着していないのに対して $U=0.79 \mathrm{~V}$ を超えると 1/3 ML の吸着 $\mathrm{OH} て ゙$ 覆われることになる。この結果は実 験的に $\mathrm{Pt}(111)$ 電極のサイクリック・ボルタモグラムで $0.8 \mathrm{~V}$ 付近に現れる酸化ピークに良く対応している. 1/3 MLよりも高い被覆率では吸着微分自由エネルギーが 急激に増えることから, さらに高い電位になると OHの 被覆率が増加するのではなく酸化 Ptが生成すると考えら れる。

酸素還元反応は, 水素酸化反応上りも複雑である。界 面でのバイレイヤー中の $\mathrm{OH}$ が, より沖合の水溶液中に あるプロトンと電極から電子を受け取って水になること が反応の初期過程と考えられる。

$$
\mathrm{H}^{+}+\mathrm{e}^{-}+\mathrm{OH}^{-} \rightarrow \mathrm{H}_{2} \mathrm{O}
$$

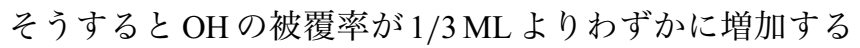
ので，バイレイヤー中の水はプロトンリレーを経て吸着 した酸素分子にプロトンを渡し, 界面バイレイヤー中の 水分子からプロトンリレーを経て水素を受け取る。

$$
\mathrm{H}_{2} \mathrm{O}^{*}+\mathrm{O}_{2}^{*} \rightarrow \mathrm{OH}^{*}+\mathrm{OOH}^{*}
$$

この繰り返しによって吸着酸素が水になるまで還元され ると考えられる。この反応経路について中間体のエネル ギーや活性化障壁を求めた結果がFig. 8 に示してある. 酸 素還元反応の最初の過程は酸素分子に水素が一つ結合し て $\mathrm{OOH}$ が生成する過程である。 $\mathrm{OOH}$ にさらに水素が一 つ結合して $\mathrm{HOOH}$ が生じる過程はエネルギー的に不安定 であるのでこの図には示していない. 一方, $\mathrm{OOH}$ が近く の水と反応して OO 結合が切れ, 二つの吸着 $\mathrm{OH}$ が生成す る過程は発熱過程である。生じた $\mathrm{OH}$ をさらに還元して 最終的に水になる。 $U=0.90 \mathrm{~V}$ での自由エネルギーダイ 


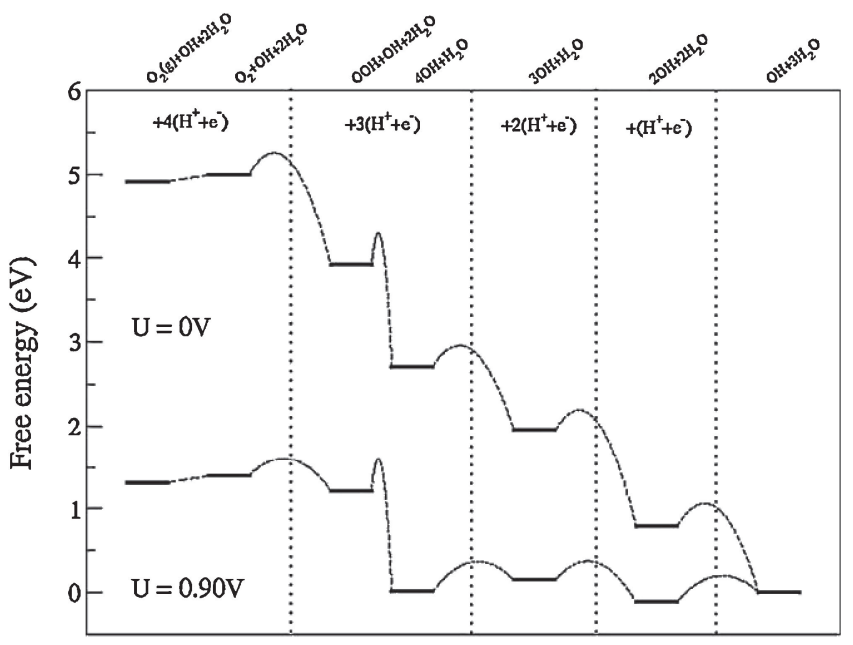

Reaction coordinate

Figure 8. 酸素還元反応の自由エネルギー・ダイヤグラム。 Reference 11 から転載.

ヤグラムを見てみると，吸着 $\mathrm{OH}$ が生じるまでは比較的 スムーズに反応が進むが，吸着 $\mathrm{OH}$ を水に還元する過程 でエネルギー障壁があることが分かる。

以上見てきた様に, 酸素還元反応過程の自由エネル ギー・ダイヤグラムの計算が可能になって来ている. 自 由エネルギー・ダイヤグラムが求まれば，反応速度論を 用いて触媒の活性を計算することが出来る。同様な計算 を他の金属について行い, より活性の高い触媒を探索す る試みが行われた ${ }^{12}$. Figure $9 b$ に $\operatorname{Pt}(111)$ 表面に加えて, $\mathrm{Pt}_{3} \mathrm{Y}$ と $\mathrm{Pt}_{3} \mathrm{Sc}$ の合金表面に $\mathrm{Pt}$ が一層吸着した表面上での酸 素還元反応の中間体の自由エネルギー・ダイヤグラムを 示す. $\mathrm{Pt}_{3} \mathrm{Y}$ と $\mathrm{Pt}_{3} \mathrm{Sc}$ 合金に一層 $\mathrm{Pt}$ が覆つた表面上では $\mathrm{OOH}$ や $\mathrm{OH}$ の中間体のエネルギーがやや不安定になって いる.そのため $\mathrm{O}_{2}$ 分子が $\mathrm{OOH}$ に還元される際には自由 エネルギー障壁が純粋な $\mathrm{Pt}$ 表面より高くなってしまって いるが，OHが水に還元される段階では逆に自由エネル ギー障壁が小さくなっていることが分かる，このように， 反応過程の自由エネルギー障壁は, 反応の中間体の安定
性, すなわち $\mathrm{OOH} や \mathrm{OH}$ の吸着エネルギーに依存して変 化する。これらの中間体の吸着エネルギーは, 酸素原子 の吸着エネルギーと良い相関を持っているので，全過程 の反応速度を酸素の吸着エネルギーの関数として図にす ると，火山型の依存性を示す。 Figure 9a に測定された電 極触媒の活性について, その電極表面への酸素の吸着工 ネルギーの関数としてプロットした結果が示されている. この図をみると酸素の吸着エネルギーが負の極限, すな わち酸素原子が強く吸着する金属表面上では $\mathrm{OH}$ を還元 して水にする段階の活性化障壁が高くなってしまい, 一 方, 酸素の吸着エネルギーが正の極限では $\mathrm{O}_{2}$ から $\mathrm{OOH}$ を生じる段階の活性化障壁が高くなってしまい，やはり 活性が低い. 活性の高い触媒は酸素の吸着エネルギーが 中間的な值をとるものになる。Ptはピークよりやや左側 にあるので, 酸素の吸着が $\mathrm{Pt}$ 表面よりも $0.2 \mathrm{eV}$ 程度弱い 金属触媒を探すと良いということがわかる。そのことを 念頭に様々な金表面上に Ptまたは Pdが一層だけ覆った表 面での酸素の吸着エネルギーを計算した結果がFig. 10 に 示されている。横軸は合金化による安定化エネルギーで あり負になるほど安定な合金である。電極触媒として使 用するには安定であることも必要条件なので，なるべく 負の合金化エネルギーを持つ金属で, 酸素の吸着エネル ギーが Pt 表面よりも $0.2 \mathrm{eV}$ 程度正の合金を探すと良い. Figure 10 から $\mathrm{Pt}_{3} \mathrm{Sc}$ と $\mathrm{Pt}_{3} \mathrm{Y}$ 合金に $\mathrm{Pt}$ を一層被覆した系が 非常に有望であることがわかる。事実, これらの合金を 用いて電極の活性を測定した結果がFig. 11 に示されてい る。計算で予測された様に $\mathrm{Pt}_{3} \mathrm{Y}, \mathrm{Pt}_{3} \mathrm{Sc}, \mathrm{Pt}$ の順で触媒が活 性であることが実験的にも確かめられた。

\section{5. おわりに}

以上述べてきた様に，従来反応速度論的な考察から反 応機構の推測が行われてきた電気化学反応の研究に対し て，第一原理シミュレーションは直接反応過程を求め, 各素過程の活性化障壁の電極電位依存性, 電極触媒依存 性も計算することが可能になりつつあり，これらの手法 を用いて新たな電極触媒の探索・設計も試みられ始めて
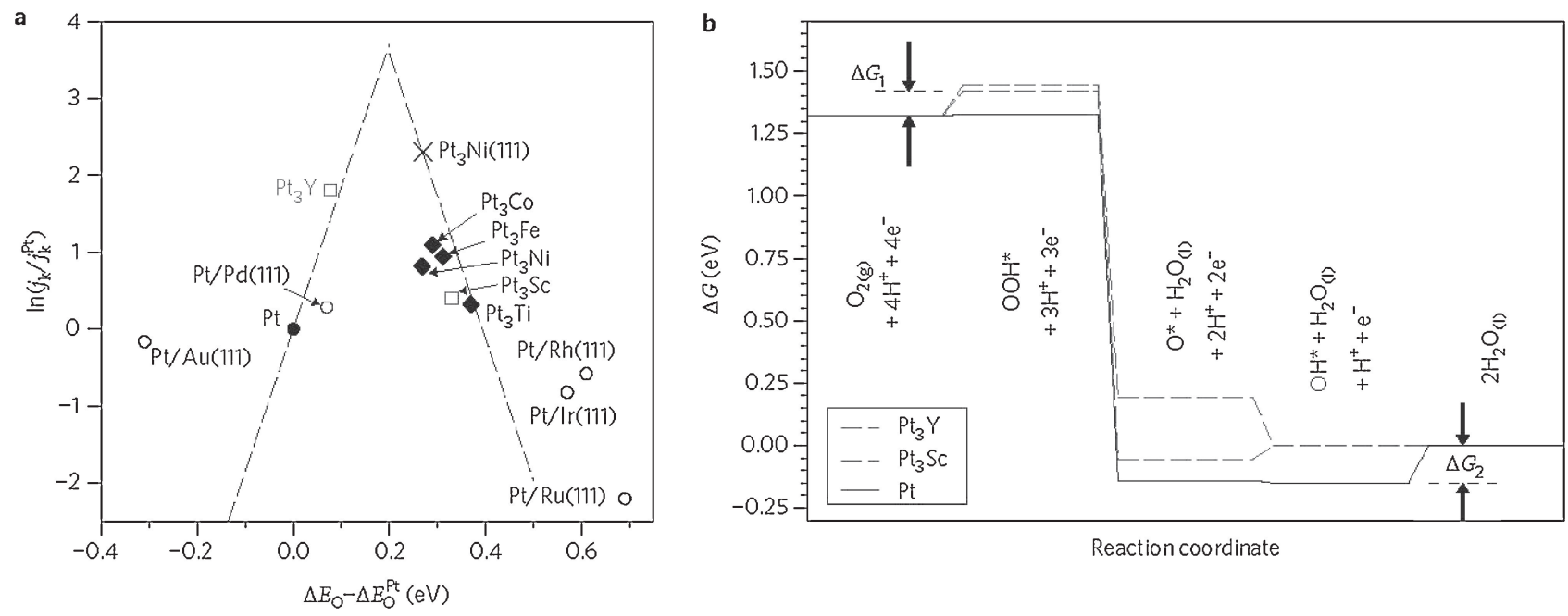

Figure 9. a. 合金電極触媒の酸素還元反応の活性を触媒表面上への酸素原子の吸着エネルギーの関数としてプロットした図. b. $\mathrm{Pt}, \mathrm{Pt}_{3} \mathrm{Sc}$, および, $\mathrm{Pt}_{3} \mathrm{Y}$ 合金表面上での酸素還元反応の中間体の自由エネルギー・ダイヤグラム. Reference 12 から転載. 


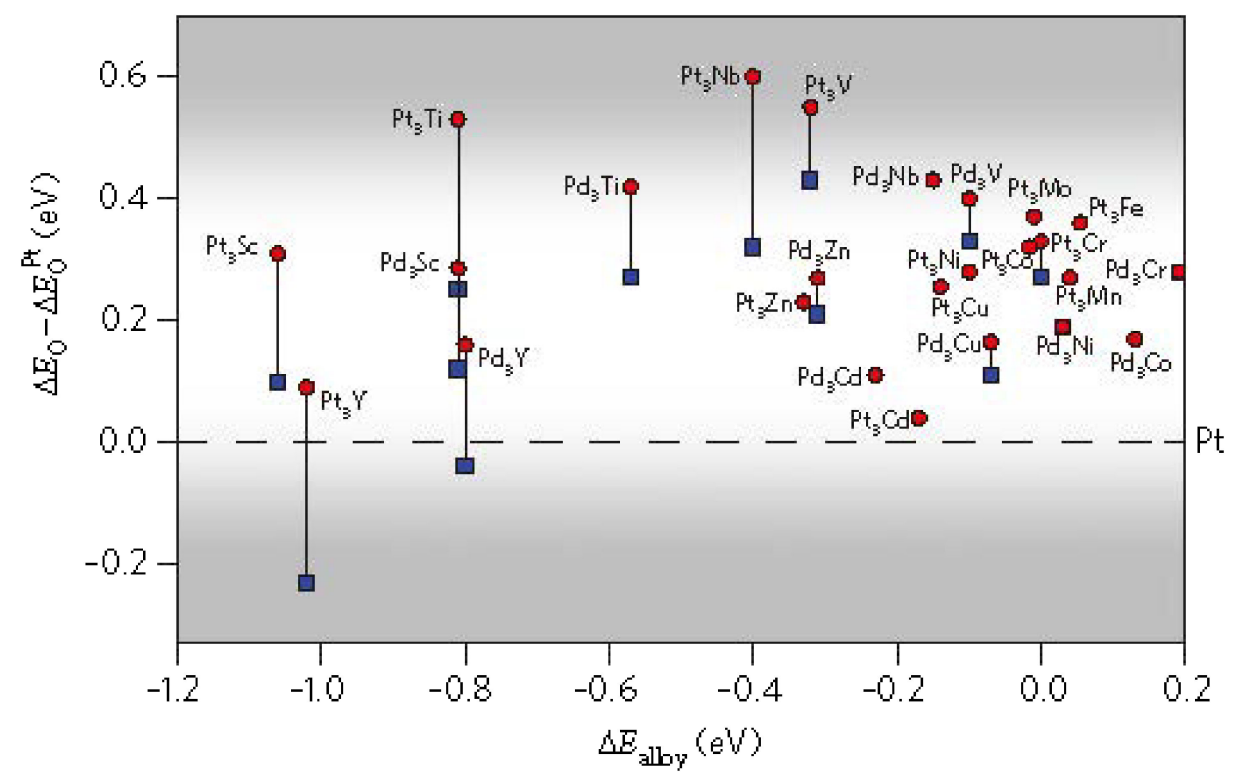

Figure 10. (Color online) 様々な合金表面上での酸素原子の吸着エネルギーを縦軸にとり，横軸に合金化エネルギーをプロッ トした図. Reference 12 から転載.

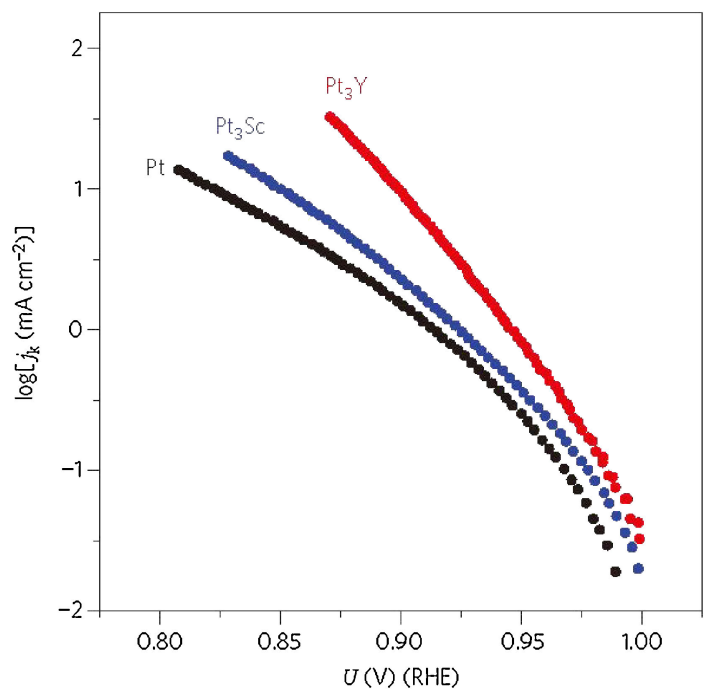

Figure 11. (Color online) $\mathrm{Pt}, \mathrm{Pt}_{3} \mathrm{Sc}$, および, $\mathrm{Pt}_{3} \mathrm{Y}$ 合金の活性 の電極電位依存性. Reference 12 から転載.

いる. 現在のところ，反応機構の解明にはかなり成功し つつある。しかしながら，第一原理計算により未知の合 金の反応性のみならず安定性についても効率的に予測す るには最適化の手法を工夫する必要がある。また，金属 触媒については比較的精度の良い計算が可能であるが, 酸化物や半導体の場合は, 現在主流として用いられてい る密度汎関数理論における一般化密度勾配近似 (GGA) で はバンド・ギャップが精度よく計算できない等，計算科 学による本格的な電極触媒設計を行うはまだまだ研究す べき課題が多いと言える.
文 献

1. Y. Morikawa, Introduction to Computational Materials Design-From the Basics to Actual Applications - (Eds. H. Kasai, H. Akai, and H. Yoshida), Osaka University Press, Osaka, Chap. 4 (2005). [in Japanese]

2. Y. Morikawa, Development of Density Functional Theory-Application to Materials Design - (Eds. H. Akai and K. Shirai), Maruzen, Chap. 7 (2012). [in Japanese]

3. O. Sugino, I. Hamada, M. Otani, Y. Morikawa, T. Ikeshoji, and Y. Okamoto, Surf. Sci., 601, 5237 (2007).

4. M. Otani, I. Hamada, O. Sugino, Y. Morikawa, Y. Okamoto, and T. Ikeshoji, J. Phys. Soc. Jpn., 77, 024802 (2008).

5. M. Otani, I. Hamada, O. Sugino, Y. Morikawa, Y. Okamoto, and T. Ikeshoji, Phys. Chem. Chem. Phys., 10, 3609 (2008).

6. I. Hamada and Y. Morikawa, J. Phys. Chem. C, 112, 10889 (2008)

7. T. Ikeshoji, O. Sugino, Y. Morikawa, M. Otani, I. Hamada, and Y. Okamoto, Electrochemistry, 77, 241 (2009).

8. Y. Morikawa and I. Hamada, Electrochemistry, 77, 248 (2009).

9. J. Rossmeisl, E. Skulason, M. E. Bjorketun, V. Tripkovic, and J. K. Nørskov, Chem. Phys. Lett., 466, 68 (2008)

10. E. Skulason, V. Tripkovic, M. E. Bjorketun, S. Gudmundsdottir, G. Karlberg, J. Rossmeisl, T. Bligaard, H. Honsson, and J. K. Nørskov, J. Phys. Chem. C, 114, $18182(2010)$

11. V. Tripkovic, E. Skulason, S. Siahrostami, J. K. Nøskov, and J. Rossmeisl, Electrochim. Acta, 55, 7975 (2010).

12. J. Greeley, I. E. L. Stephens, A. S. Bondarenko, T. P. Johansson, H. A. Hansen, T. F. Jaramillo, J. Rossmeisl, I. Chorkendorff, and J. K. Nørskov, Nat. Chem., 1, 552 (2009).

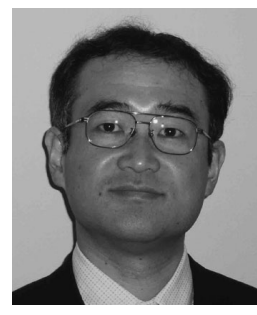

森川 良忠（大阪大学大学院工学研究科精密科 学・応用物理学専攻・教授

1966 年生. 1994 年 3 月東京大学大学院理学系研 究科博士課程修了, 博士 (理学)。1994-95 年日 本学術振興会特別研究員 (PD), 1995-01 年 通商 産業省工業技術院産業技術融合領域研究所に て界面反応の研究，2004 年より大阪大学助 教授, 准教授を経て，2009年10月より現職. 2009年日本物理学会論 文賞. 専門分野：固体電子論・量子シミュレーション。趣味：読書. E-mail：morikawa@prec.eng.osaka-u.ac.jp 